\title{
Hybridization in American TV Commercials
}

\author{
Jana Pelclová

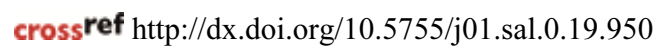

\begin{abstract}
Since advertising represents one-way, public communication the message of which is to sell the product being advertised, the persuader's task is to background the persuasive intention of the message in order to mitigate the negative impact of the persuasiveness. Simultaneously, the persuader has to support the persuadee's trust in the product's quality and usefulness. From the point of view of linguistics, this means that the persuader combines features related to formality, impersonality and detachment, with those connected with informality, personality and involvement. In other words, the discourse of advertising mingles elements of writtenness with the elements of spokenness to make the advertising message more acceptable but still credible. The elements can be found on every linguistic level. Advertising communication thus becomes a private, colloquial interaction where the persuader treats the persuadee respectfully as a social equal. The objective of the present paper is to analyze the way the three language entities, the secondary participant, the voice-over and the super, participate in the process of hybridization in TV advertising for products of everyday use.
\end{abstract}

Key Words: advertising, hybridization, spokenness, writtenness, persuasion.

\section{Introduction}

Following Lakoff (1982, p.28), a discourse is considered persuasive when "the intent to persuade is recognized explicitly as such by at least one party to the discourse". In the case of advertising, both parties recognize this intention since consumers are fully aware of the persuasive intention that is encoded in every advertising message. In order to mitigate the negative aspect connected with its persuasive function, the discourse of advertising operates with a number of camouflaging devices. One of them is the employment of the discourse of ordinary conversation (cf. Myers, 1994; Goddard, 2002; Cook, 1992) because this non-persuasive discourse type is the opposite of unilateral, public and non-reciprocal interaction which advertising communication represents. However, advertising is not, and never will be, a face-to-face interaction like that we know from real-life situations. There are two main reasons for this argument: first, an advertising text is a written-tobe-performed text (therefore, everything is pre-arranged, hence not spontaneous); secondly, the participants' rights differ from the rights of the participants of an ordinary conversation. Despite this disparity, advertising inclines to be structured as a piece of friendly interaction between the speaker, the persuader, and the receiver, the persuadee. As a result, the discourse of advertising borrows linguistic features typical of spoken language. Besides its spokenness, however, its written-to-be-performedness suggests that it also contains features found in written language. In other words, advertising can be identified as a hybrid form of communication that mingles elements of spokenness with the elements of writtenness (Urbanová, 2006, p.174).

Assuming that spokenness and writtenness are predominantly represented by the discourse of ordinary conversation and that of legal documents, respectively, it can be presumed that elements of these two language varieties are integrated in the discourse of advertising on both lexico-grammatical and pragmatic levels. The question that arises here is which linguistic elements typical of spokenness and which elements typical of writtenness prevail in advertising and how exactly TV advertising integrates these elements into commercials for products of everyday use. Additionally, the article focuses on what function the process of hybridization has in advertising discourse.

\section{Language Entities of TV Advertising}

Owing to its audio-visuality, TV advertising can operate with three language entities: the voice-over, the secondary participant and the super. The voice-over stands for an offthe-screen commentary that either corresponds with what is happening on the screen or provides a verbal explanation of what has just happened on the screen. The term secondary participant includes those participants that are visible on the screen and are involved in a dialogical situation either between themselves or directly with the persuadee when turning to the camera and addressing a TV viewer. Depending on a marketing strategy, however, this entity can be also verbally passive, which means that the secondary participant is displayed but does not say anything. The entity of the super refers to the text superimposed on the screen. According to its informative value, two types of this last language entity can be distinguished. The first type represents a text that underlines information the persuader considers crucial for the purchase of the product. The other type is represented by a piece of text the informative value of which is not so important but needs to be provided due to the legitimacy of a commercial, e.g.

These statements have not been evaluated by the Food \& Drug Administration. This product is not intended to diagnose, treat, cure or prevent any disease (Osteo Bi-Flex).

Definitely, this piece of information is a less decisive factor at the point of purchase. For the purpose of the article, the former is distinguished as the super with higher informative value, while the latter is the super with lower informative value. The informative value of these two super types is of course reflected in their graphic layout and on-the-screen location. 


\section{Two Language Varieties}

Crystal (1989, p.179) understands the spoken and the written varieties as "alternative, 'equal' systems of linguistic expression". The existence of these two systems is to a certain degree determined by a number of social and cultural aspects (cf. Holmes, 1996, Halliday, 1978). Regardless of their extralinguistic reality, the linguistic differences between the two language varieties can be summarized in the following way. The spoken variety is mainly represented in the discourse of ordinary conversation, where the participants share the same spatial and temporal setting. Depending on their social status and relationship, the participants prefer informal vocabulary with the tendency towards vagueness and ambiguity. As far as the grammatical level is concerned, the spoken variety is characterized by loose constructions, reformulations, hesitations, etc. The inexplicitness that is typical of an impromptu speech results in semantic indeterminacy (Urbanová, 2003). Consequently, the participants have a tendency towards the violation of the cooperative principle while following and observing the politeness principle (cf. Grice, 1975, Leech, 1991, Thomas, 1995).

By contrast, the written variety is mainly represented by the discourse of public notices and legal documents, where the spatial and temporal setting of the participants differs. Unlike in spokenness, there is the divergence of the contexts of message production and that of perception. Writtenness is related to formal vocabulary, objectivity, in some cases to terminology and to grammatical constructions that do not allow for ambiguity. Besides being formal and objective, the written variety has a tendency to be impersonal, due to a higher occurrence of passive constructions and non-finite clauses. In Tannen's term (as cited in Roberts and Street, 2004, p.170), the spoken variety is characterized by involvement, whereas the written one by detachment. It does not mean, however, that the written variety cannot demonstrate a certain degree of involvement and vice versa. In such cases, the written variety can be characterized as "oral-like" while the spoken one is then seen as "writtenlike" (Chafe as cited in Roberts and Street, 2004, p.170). An advertising text seems to be an ideal environment for composing a written-like message with an oral-like structure.

\section{Material Under Investigation}

The material includes American TV commercials that were collected in 2005 and were analyzed in the author's dissertation thesis research (see Pelclová, 2010). The advertisements were recorded from a number of American TV networks. The choice of the networks was determined by an effort to include channels with entertainment, educational, as well as informative programs. The recorded commercials contained several types of advertising, e.g. social advertising (e.g. New Orleans Charity after hurricane Katrina or an anti-drug campaign) or announcements for upcoming TV programs (e.g. Unsolved History on Discovery Channel or PM Edition on The Weather Channel), but the most broadcast type was the one that focused on the increasing profits. This type (known as product or commercial advertising) contained altogether 556 advertisements. The most advertised commodities within this particular type are listed in the table below.
Table 1. Most Advertised Commodities of 556 Product/ Commercial Advertising.

\begin{tabular}{|l|l|}
\hline Commodity & Percentage of Occurrence, $\%$ \\
\hline Food Products & 16 \\
\hline Cosmetic Products & 11 \\
\hline Medical Products & 9 \\
\hline Cars & 9 \\
\hline Beverages & 8 \\
\hline Total & $\mathbf{5 3}$ \\
\hline
\end{tabular}

The prevailing commercials were those that promoted ordinary products such as shampoos, special menus offered by fast food establishments, beer etc., while commodities such as electronic devices or clothing or services such as mortgages or insurances were less than $5 \%$. Therefore, they were not taken into consideration.

In order to provide a valuable analysis of comparable data, the material under investigation consists of commercials for products of a similar character. Therefore, the commercials for consumer durables — the cars — were excluded. As a result, the material contains 80 commercials that advertise everyday products, namely food products, cosmetic products, medical products and beverages. Each commodity is represented by 20 commercials.

A TV commercial operates with three communicative codes, namely verbal, pictorial/ visual and acoustic/ audio, the cooperation of which is inevitable for a successful delivery of the message. However, the present paper excludes the contribution of pictures and sound on message delivery and its primary interest is aimed at the language used. Even though the author's original research is initiated by eight hypotheses, they can be simplified for the purpose of this paper. Considering the nature of the commercials, it can be assumed that the entity that inclines towards spokenness most is the secondary participant, while the other two tend to be more written-like.

\section{Research Methodology}

As mentioned above, the article presents the findings of the author's dissertation thesis that is based on a qualitative research method.

As far as the lexico-grammatical analysis is concerned, it consists in analyzing the presence or absence of the following lexico-grammatical features:

1. informal expressions,

2. formal expressions,

3. terms,

4. deictic expressions,

5. discourse markers,

6. interjections,

7. hesitators,

8. response forms,

9. ellipsis,

10. vernacular language,

11. non-finite clauses,

12. verbless clauses, 
13. active constructions,

14. passive constructions.

Following the latest studies comparing the language of ordinary conversation and the language of written documents, e.g. Biber, et al. 1999, Leech and Svartvik 2002, etc., these features are regarded as the most representative of these two language varieties. This research is not quantified since some of the categories may overlap such as formal expressions and technical, or rather pseudotechnical terms in commercials for cosmetics (e.g. multi-tonal or kromashine formulas).

As far as the pragmatic analysis is concerned, the research aims at the manner the cooperative and the politeness principles are treated. The analysis focuses on whether a maxim is observed, violated or even backgrounded, which means that it is not in the persuader's intention to observe or violate it; in other words, the persuader does not follow it in his or her interaction. Consequently, the employment of the maxims is connected with the use of speech acts. Unlike the employment of the lexico-grammatical features and of the cooperative and politeness principles, the paper offers a quantitative research of speech acts used in the analyzed commercials. Their total numbers are provided in the next chapter.

\section{The Results of the Investigation}

It is important to realize that the process of hybridization in advertising discourse has an inconsistent extent in accordance with what is being advertised to whom. This means that the product and its social and material values have an impact on which elements of spokenness and which elements of writtenness will be used in a commercial. In other words, the hybrid tendencies found in the analyzed commercials can be projected into an axis or a scale with spokenness on one side and writtenness on the other. In the following figure, SP stands for the secondary participant, SHIV for the super with higher informative value, $\mathrm{V}-\mathrm{O}$ for the voice-over and SLIV for the super with lower informative value:

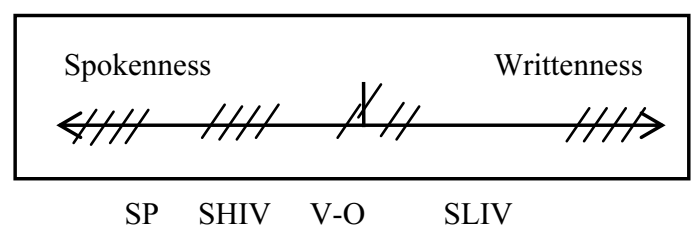

Figure 1. Spokenness-Writtenness Scale.

Considering the secondary participant, it has a tendency to be the most oral-like entity. The voice-over, on the other hand, balances somewhere around the middle, but in most cases, it is more written-like than spoken-like. As far as the entity of the super is concerned, there is a disagreement between the two super types. While the super with higher informative value is more oral-like, the super with lower informative value is the entity that adopts primarily features of writtenness.

Unlike the other two entities, the entity of the secondary participant employs familiarizers, a type of vocatives that indicate a familiar, close relationship between the speaker and the hearer (Biber, et al. 1999, p.1109). They can be found, for example in the commercial for Budweiser: "One word, buddy, Amsterdam, huh?!", or for Friday's Wild or Mild Menu: "Hey guys, ready to order?" Besides, the secondary participant prefers phrasal verbs, vague expressions, discourse markers, e.g. Well, nice Jimmy Dean people chopped this for me" (Jimmy Dean Sandwiches), interjections that can serve several functions such as hesitators, e.g. "Er, I was thinking about getting a French Dip" (Arby's French Dip), or "I used to think — sex life. Hmm. That's gonna fit somewhere in between kids, work, cleaning, stress" (Avlimil). These informal expressions mainly prevail in commercials for the special menus offered by a number of fast food establishments.

Among other features of spokenness, the secondary participant uses elliptical structures, mainly the initial ellipses, especially in a question, e.g. "Too old for breakouts? Too young for wrinkles?" (Neutrogena Anti-Wrinkle, AntiBlemish Cleanser). The entity of the secondary participant also employs echo-questions, e.g. "Shampoo? It's personal" (L'Oréal Vive), or "Spark? You wanna know where the spark went?"(Avlimil). This type of question is based on the repetition of the preceding structure (Biber, et al., 1999). By repeating the rhematic part of a preceding utterance the secondary participant can take his or her time in order to think about the answer. It is a highly contextdependent element of spoken discourse that allows the participants to govern and direct the interaction. An echoquestion is created when the secondary participant turns directly to the camera as if having a conversation with the persuadee. Its occurrence enhances the persuadee's involvement in the advertising communication since it manipulates the persuadee into feeling that some preceding question of his or her own prompted the secondary participant's answer.

Before considering the pragmatic level, Table 2 offers the overview of the speech acts used by the three language entities.

Table 2. Total Numbers of Speech Acts Used by the Individual Language Entities.

\begin{tabular}{|l|r|r|r|r|r|r|}
\hline & Assert & Direct & Comm & Express & Decl & Total \\
\hline$S P$ & 298 & 66 & 5 & 161 & 0 & $\mathbf{5 3 0}$ \\
\hline$V-O$ & 223 & 53 & 6 & 14 & 0 & $\mathbf{2 9 6}$ \\
\hline$S H I V$ & 160 & 50 & 0 & 5 & 0 & $\mathbf{2 1 5}$ \\
\hline$S L I V$ & 158 & 16 & 0 & 0 & 0 & $\mathbf{1 7 4}$ \\
\hline Total & $\mathbf{8 3 9}$ & $\mathbf{1 8 5}$ & $\mathbf{1 1}$ & $\mathbf{1 8 0}$ & $\mathbf{0}$ & $\mathbf{1 2 1 5}$ \\
\hline
\end{tabular}

Like in Figure 1, SP refers to the secondary participant, V$\mathrm{O}$ to the voice-over, SHIV to the super with higher informative value, and SLIV to the super with lower informative value. Following Searle's (1970) typology, the speech acts are classified as assertives, directives, commissives, expressives and declarations.

The reason why the assertive speech acts are the most frequent is that it enables the persuader to provide as much product information as possible. The use of directives reflects the persuader's appeal to the persuadee while the 
expressive speech acts reflect mostly the persuadee's mental state, usually what he or she thinks about the product being advertised as it is predominantly used by the entity of the secondary participant. Surprisingly, the persuader avoids commissives as a commercial hardly wants to promise; instead it claims that something is true. The absence of declarations is caused by the lack of a contextual situation (e.g. baptizing a child) in which a declarative speech act would be used.

Besides assertives, the entity of the secondary participant operates with expressive and directive speech acts, e.g. "Nice nose, Oven Mitt" (Arby's New Five-Star Club), or "Come on, gimme some skin" (Heineken). As in a real-life situation, the secondary participant has a tendency to violate the cooperative principle. However, in an ordinary conversation, the violation is caused by the speaker's intention not to express the meaning directly. There might be several reasons for this. For instance, the speaker may be restricted by socio-cultural conventions; so, in order to behave in a socially acceptable way, he or she has to follow a set of conventional rules that are also reflected in his or her speech behavior. Whatever the reason, owing to the context and also to the interlocutors' relationship, the hearer should be able to derive what the speaker wants to say. In other words, the speaker implies the meaning while the hearer should be able to infer it correctly (Thomas, 1995, p.58).

In advertising communication, however, the reason why the entity of the secondary participant violates the cooperative principle is subordinated to the primary function of every advertisement: the endeavor to sell a product. Therefore, the secondary participant's role is to offer as much product information as possible no matter how unusual his or her speech performance might appear. For instance, in the commercial for the Canadian beer Labatt Blue, one of the secondary participants is a bear that acts like a human being. In the commercial, he is applying for the job of a bartender. Irrespective of this bizarre situation, the bear is socially and professionally mature. When a young customer comes to the bar and asks for Labatt Blue, the bear reaches for the bottle, opens it and passes it to the young lady. What probably draws her attention more than the presence of the bear behind the counter are the words he uses when passing her the bottle. Instead of saying Here you go or Five bucks, for example, the bear says: "I've got this one. Hahaha. Canada's finest". This is a rather peculiar verbal accompaniment for the serving of a beer. From the point of view of pragmatics, the bear violates the maxims of relevance, quantity and manner as far as the context of serving a beer is concerned. Within the context of the commercial, however, it might be claimed that the bear follows these maxims since he informs the persuadee about the quality of the advertised product. In other words, the persuadee is able to infer what the persuader wants him to get to know via the bear's verbal performance.

While the above-described features prevail in commercials for beverages, food and medical products, the secondary participant in commercials for cosmetics incline towards writtenness. Their written-like tendency is reflected in the use of formal expressions, terms, and even passive voice, e.g. "Each L'Oréal is designed to target any specific hair type. I've found mine. Smooth intense with nutrilium" (L'Oréal Vive). The reason for this higher level of formality and impersonality is the target group itself — women. According to Holmes (1995) women pay more attention to what is said and how it is said.

Besides lexico-grammatical differences, there is also a divergence between the entity of the secondary participant featured in cosmetic commercials and the one in commercials for beverages, food and medications on the level of pragmatics. This is caused by the way the secondary participant provides the product information. While the secondary participant in non-cosmetic commercials mentions just some of the key features, the one in cosmetic commercials provides as much product information as possible. Moreover, the secondary participant in the analyzed commercials for cosmetic products is always involved in a dialogical situation with a TV viewer, which means that the women depicted (both famous celebrities and ordinary women) have a face-to-face interaction with the persuadee. This tactic is supposed to enhance the persuadee's involvement and engagement in the advertising communication. Plus the message seems to be more acceptable, considering the number of identical cosmetic products available on the market. From the point of view of pragmatics, this has an impact on the employment of the approbation maxim. Since the secondary participant in the female cosmetic commercials maximizes the product's positive aspects, such as its cleansing qualities, shining effects, perfect make-up coverage, etc., not only does the entity observe the cooperative principle, but at the same time, it observes the approbation maxim. In the other commercials in question, this particular maxim is employed and observed by the entity of the voice-over. The maximization of the product's praise is realized by assertive speech acts. Besides the approbation maxim, female cosmetic commercials also endeavor to maximize the agreement between the persuader and the persuadee. Therefore, the majority of these commercials begin with a statement that seeks for an agreement such as the one used by Andie MacDowell in L'Oréal Revitalift commercial: "When you are fortyish you want an intense defense against aging".

A tendency that is evident across the commercials under investigation is that the entity of the voice-over balances around the middle of the spokenness-writtenness scale, inclining more towards writtenness. This means that it adopts some features of spoken discourse, such as informal expressions, ellipsis, vernacular language, e.g. "Wanna know a secret?" (Ensure), but unlike the secondary participant, there are no examples of discourse markers or interjections.

As far as the lexical level is concerned, the voice-over often combines formal and informal expressions: but, in some cases, the formal vocabulary prevails, as in commercials for fast food products. The voice-over uses this type of vocabulary in order to introduce the ingredients that the special menu-offers contain. On the other hand, formal vocabulary is used in independent verbless clauses, which means that the voice-over merges the lexical writtenness 
with the grammatical spokenness. For instance, the male voice-over in the commercial for Taco Bell Grilled Stuft Burrito combines formal culinary expressions with phrasal verbs and structures them in independent clauses:

The new Chipotle Grilled Stuft Burrito. Loaded with carne asado steak, chipotle season rice, spicy southwest chipotle sauce and a blend of three melted cheeses. All wrapped up and grilled to go. For the perfect balance of flavor and spice. Think outside the bun.

The fact that the voice-over inclines towards writtenness more than it does for the secondary participant is also reflected in its employment of pragmatic principles. In order to provide as much product information as possible, the voice-over always prefers observing the cooperative principle. Nonetheless, the amount of product information differs according to the topic: beer commercials do not offer more than the name of the beer and the slogan meant to represent the social values associated with the consumption of that particular brand; commercials for medical products, on the other hand, endeavor to include as many facts as one can find in the leaflet attached to a medication, e.g., who should not take the product, what the side effects are, etc. Regardless of the amount, the voiceover communicates the product's unique features and, at the same time, distinguishes it from similar products on the market. Consequently, the voice-over's task is to observe the approbation maxim by maximizing the product's praise.

The offer of the product information also has an impact on the speech acts which the entity of the voice-over uses. Besides assertives, the voice-over often operates with directives. This type of speech act appears mostly in slogans. Since the directives appeal for the persuadee to engage in a certain beneficial action, they are interpreted as acts maximizing the benefits to the persuadee. The directives thus participate in the observance of the tact maxim, e.g. "Love the skin you're in" (Olay commercials) or "When you have it all, treat it all" (Maalox Max).

Like the secondary participant in the commercials for cosmetic products, its voice-over observes the agreement maxim. The same maxim is also observed by the voiceover in those commercials that promote pre-packaged meals. For instance, the female voice-over in the commercial for Asian Sensation starts her contribution by "When the family is hungry, you'll hear about it". Women are more likely to show agreement when they are offered a statement which they can hardly fail to agree.

The last entity that operates with language is the superimposed text. As written above, there are two types of this entity, the super with higher informative value and the super with lower informative value. The division reflects the persuader's assessment of the significance of the information provided. The former highlights the product's key features that are often provided by the spoken entities. As such, the super with higher informative value functions as an echo of the secondary participant and/ or the voiceover. The latter, on the other hand, enlarges the amount of information provided as it offers additional information about the product. Needless to say, this additional information is considered be less significant. Accordingly, the former is more spoken-oriented while the latter is rather writtenoriented.

The super with higher informative value prefers informal vocabulary combined in independent verbless clauses. These clauses are mainly represented by nominal or adjectival phrases, e.g. "The not-so-vanilla vanilla" (Pepsi Vanilla), "weightless, flawless" (Almay Nearly Naked), but there are also examples of prepositional phrases, e.g. "from the makers of Pepsi" (Sierra Mist). Owing to its rather abbreviated character, this particular super type is seen as observing the cooperative principle. As already stated, the super with higher informative value superimposes the text that is uttered by the other two entities. From the point of view of relevancy and adequacy, however, the repetition might be interpreted as a violation of the maxim of relation since the persuader thus provides information already provided. Even though repeating the key phrase might be irrelevant and inadequate, its task is to increase the level of memorability. On the other hand, it helps to maximize the product praise or the benefits to the persuadee. As a result, it observes the approbation maxim and the tact maxim. The former is usually achieved by an assertive speech act, while the latter is achieved by directives.

The super type with lower informative value prefers formal expressions. The formal vocabulary can be combined in independent verbless clauses, e.g. "At participating restaurants. For a limited time" (Friendly's). In most cases, however, the formal expressions are used in more complex grammatical structures, e.g.

Some risk factors include: Caucasian/ Asian race, family history, small frame and smoking. Actonel is for the prevention and treatment of postmenopausal osteoporosis (Actonel),

"A dietary supplement, to be used daily, as directed: not an analgesic" (Osteo Bi-flex). Since it provides an adequate amount of information in an unambiguous way, this super type always observes the cooperative principle. On the other hand, it can provide information that rather minimizes the product's praise, instead of maximizing it as the spoken entities do. Examples can be found in the commercials for fast food special menu-offers or for medical products where the information about the time and space limitation of the special menu-offers and about the non-approval of the utterances by authorized associations are displayed on the screen. As a result, such statements can be interpreted as violating the approbation maxim as far as the maximization of product praise is concerned.

\section{Conclusion}

The paper offers an analysis of the process of hybridization in American TV commercials for products of everyday use, namely beverages, food, cosmetic and medical products. In accordance with the product character, the target group of the commercials has an impact on the level of hybridization. In other words, the persuader-persuadee relationship is reflected in the way the individual language entities a TV commercial includes employ the features of spokenness and of writtenness. The hybrid tendencies on the syntactic level, such as the lexical writtenness and the grammatical spokenness are then observable in the preference for particular 
speech acts and observance and/ or non-observance of the individual maxims of the cooperative and politeness principles. The hybridization thus enables the persuader to reduce the anonymity of the advertising communication and at the same time to treat the persuadee with respect and solidarity. On top of that, the elements of spokeness allow the persuadee to be more involved in a rather unilateral interaction resulting from the nature of advertising communication. The task of the individual entities is then to keep the adopted spoken and written elements in balance so the whole message is more acceptable and credible. Consequently, it can be claimed that the process of hybridization functions as a persuasive strategy advertisers use in order to shift the advertising communication onto more private level and thus to increase the effectivity of a commercial.

Further research might focus on commercials for different types of commodities, especially consumer durables such as cars or luxuries, in order to discover whether the entities treat the spoken and written tendencies differently.

\section{References}

1. Biber, D., et al., 1999. Longman Grammar of Spoken and Written English. London: Longman.

2. Cook, G., 1992. The Discourse of Advertising. London: Routledge.

3. Crystal, D., 1989. The Cambridge Encyclopedia of Language. Cambridge: CUP.

4. Goddard, A., 2002. The Language of Advertising. London: Routledge.

5. Grice, H. P. 1975. Logic and Conversation. Syntax and Semantics, vol. 3: Speech Acts. Peter, C. and Morgan, J. L. (eds.) New York: Academic

Jana Pelclová

\section{Hibridizacija amerikietiškoje TV komercinèje reklamoje}

\section{Santrauka}

Šiame straipsnyje nagrinėjamas amerikietiškų TV reklamų tekstų hibridizacijos procesas. Jame analizuojami sakytinės ir rašytinės kalbos leksiniai ir gramatiniai bruožai, ypatingą dèmesị skiriant individualių bendravimo ir mandagumo principų laikymuisi ir/arba jų pažeidimui. Lingvistiniu požiūriu tai reiškia, kad reklamoje turi būti derinami formalumo, neasmeniškumo ir nešališkumo bruožai su neoficialumu, asmeniškumu ir suinteresuotumu. Reklamos kalba sulieja rašomosios kalbos elementus su kalbejjimo elementais, siekiant, kad reklamos pranešimas būtų labiau priimtinas ir įtikinamas. Nagrinėjamoji medžiaga - 80 reklamos tekstų, skirtų reklamuoti kasdieninio vartojimo produktus. Tyrimo tikslas yra išanalizuoti, kaip trys kalbiniai komponentai - dalyvio kalba, balsas už kadro ir tekstas ekrane sąveikauja reklamos hibridizacijos procese. Tyrimas atskleide, kad dalyvaujantys asmenys vartoja sakytinę kalbą, teksto ekrane kalba yra rašytinė. Balsas už kadro derina sakytinę ir rašytinę kalbą, nors dažniau pasitaiko rašytinės kalbos bruožų.

\section{About the author}

Jana Pelclová, PhD., assistant professor, Department of English and American Studies, Masaryk University, Brno, Czech Republic. Research interests: pragmatics, discourse analysis, process of hybridization, sociolinguistics. Address: Department of English and American Studies, Masaryk University, Arne Novaka 1, Brno 602 00, Czech Republic. E-mail: pelclova@phil.muni.cz 